\title{
Targeting xCT, a cystine-glutamate transporter induces apoptosis and tumor regression for $\mathrm{KSHV} / \mathrm{HIV}$-associated lymphoma
}

\author{
Lu Dai ${ }^{1,3 \dagger}$, Yueyu Cao ${ }^{1 \dagger}$, Yihan Chen ${ }^{1}$, Chris Parsons ${ }^{3}$ and Zhiqiang Qin ${ }^{1,2^{*}}$
}

\begin{abstract}
Kaposi's sarcoma-associated herpesvirus (KSHV) is the etiological agent of primary effusion lymphoma (PEL), which represents a rapidly progressing malignancy arising in HIV-infected patients. Conventional chemotherapy for PEL treatment induces unwanted toxicity and is ineffective - PEL continues to portend nearly $100 \%$ mortality within a period of months, which requires novel therapeutic strategies. The amino acid transporter, $x C T$, is essential for the uptake of cystine required for intracellular glutathione (GSH) synthesis and for maintaining the intracellular redox balance. Inhibition of $x C T$ induces growth arrest in a variety of cancer cells, although its role in virus-associated malignancies including PEL remains unclear. In the current study, we identify that $x \mathrm{CT}$ is expressed on the surface of patient-derived $\mathrm{KSHV}^{+}$PEL cells, and targeting $x \mathrm{CT}$ induces caspase-dependent cell apoptosis. Further experiments demonstrate the underlying mechanisms including host and viral factors: reducing intracellular GSH while increasing reactive oxygen species (ROS), repressing cell-proliferation-related signaling, and inducing viral lytic genes. Using an immune-deficient xenograft model, we demonstrate that an $x C$ T selective inhibitor, Sulfasalazine (SASP), prevents PEL tumor progression in vivo. Together, our data provide innovative and mechanistic insights into the role of $x C T$ in PEL pathogenesis, and the framework for xCT-focused therapies for AIDS-related lymphoma in future.
\end{abstract}

Keywords: $\mathrm{KSHV}$, Herpesvirus, $x \mathrm{CT}$, Lymphoma

\section{Introduction}

The oncogenic $\gamma$-herpesvirus known as the Kaposi's sarcoma-associated herpesvirus (KSHV) is a principal causative agent of cancer arising in patients with compromised immune systems [1]. One of these cancers, primary effusion lymphoma (PEL), comprises transformed B cells harboring KSHV episome and arises preferentially within the pleural or peritoneal cavities of patients infected with HIV [2]. PEL is a rapidly progressing malignancy with a median survival time of approximately 6 months [3]. Currently, combinational chemotherapy is the standard of care for PEL, and cyclophosphamide, doxorubicin, vincristine,

\footnotetext{
* Correspondence: zqin@|suhsc.edu

${ }^{\dagger}$ Equal contributors

${ }^{1}$ Research Center for Translational Medicine and Key Laboratory of Arrhythmias of the Ministry of Education of China, East Hospital, Tongji University School of Medicine, 150 Jimo Road, Shanghai 200120, China 2Department of Microbiology/lmmunology/Parasitology, Louisiana State University Health Sciences Center, Louisiana Cancer Research Center, 1700 Tulane Ave., New Orleans, LA 70112, USA

Full list of author information is available at the end of the article
}

and prednisone $(\mathrm{CHOP})$ regimens are considered first-line therapy $[4,5]$. However, the myelosuppressive effects of systemic cytotoxic chemotherapy synergize with those caused by antiretroviral therapy or immune suppression $[3,4,6]$. Several novel approaches for PEL therapy have been reported in recent studies and increase survival for some patients, but a lack of sufficient safety and efficacy data have precluded their routine use. The proteasome inhibitor bortezomib and the combination of arsenic trioxide and interferon both suppress the NF- $\mathrm{kB}$ activation and may work synergistically with cytotoxic chemotherapy to reduce PEL viability $[7,8]$. Unfortunately, proteasome inhibition and arsenic incur significant toxicities limiting their clinical application. The mammalian target of rapamycin (mTOR) inhibitor, sirolimus inhibits PEL cell growth in a murine xenograft model [7], but which paradoxically induces expression of the serine/threonine kinase Akt and tumor cell growth, resulting in treatment failures [8]. Recently, we report that inhibition of sphingosine kinase 2 (SphK2) by a novel compound, ABC294640, effectively prevents and 
represses PEL tumor progression in vivo [9]. Even though, novel targeted, safer and more effective strategies are urgently needed for PEL treatment.

The $\mathrm{x}_{\mathrm{c}}{ }^{-}$antiporter, consisting of $\mathrm{xCT}$ (also named as SLC7A11) and its chaperone CD98, functions as a $\mathrm{Na}^{+}$-independent electroneutral exchange system for cystine/glutamate [10]. Expression of $\mathrm{xCT}$ on the cell membrane is essential for the uptake of cystine required for intracellular glutathione (GSH) synthesis, which plays an important role in maintaining the intracellular redox balance [11,12]. Cystine/cysteine represents an essential amino acid for many cancer cells and its uptake from the microenvironment is crucial for their growth and viability. Therefore, $\mathrm{xCT}$ is highly expressed by a variety of malignant tumors [13-16], and also contributes to multidrug resistance for cancer cells $[17,18]$.

Interestingly, $\mathrm{xCT}$ has been also identified as a fusionentry receptor for KSHV and mediated KSHV entry either in isolation or as part of a complex with other receptors for the virus $[19,20]$. Recently, our study has demonstrated that $\mathrm{xCT}$ is upregulated within more advanced Kaposi's sarcoma (KS, another KSHV-caused malignancy) lesions containing a greater number of KSHV-infected cells [21]. Moreover, xCT can be upregulated by $\mathrm{KSHV}$-microRNAs by directly targeting $\mathrm{BACH}-1$, one of the negative transcription regulators of $\mathrm{xCT}$, thereby facilitating viral dissemination and persistence in the host [21]. In the same study, we also report that $\mathrm{xCT}$ protects KSHV-infected endothelial cells from death induced by reactive oxygen species (ROS) [21]. In another our recent study, we report that $\mathrm{xCT}$ is able to activate intracellular signaling pathways especially MAPK, cytokine release and cell invasiveness through induction of 14$3-3 \beta$ protein [22]. Even though these understandings about $\mathrm{xCT}$ and $\mathrm{KSHV}$ pathogenesis, it remains unclear whether $\mathrm{xCT}$ is also expressed on KSHV-infected PEL tumor cells and its functions in PEL pathogenesis especially tumor cells growth/survival and underlying complex mechanisms. More importantly, it is interested to know whether targeting $\mathrm{xCT}$ may represent a promising therapeutic strategy against PEL tumor progression in vivo.

\section{Results}

\section{xCT is highly expressed on KSHV-infected PEL cell-lines}

To first identify whether $\mathrm{xCT}$ is expressed on KSHVinfected PEL cells, we tested its expression in $3 \mathrm{KSHV}$ infected PEL cell-lines BC-1, BCP-1 and BCBL-1 (BC-1 was also $\mathrm{EBV}^{+}$) using immunoblots. Our data demonstrated the expression of $\mathrm{xCT}$ in all $3 \mathrm{KSHV}$-infected PEL cell-lines but no significant difference at its expressional levels among these cell-lines (Figure 1A). Next, using a monoclonal Ab recognizing an extracellular domain of $\mathrm{xCT}$ in flow cytometry, we confirmed that $\mathrm{xCT}$ is highly expressed on the cell surface of KSHV-infected PEL cell-lines including BCP-1 and BCBL-1. Moreover, RNAi targeting xCT successfully reduced its expression on cell-surface and total cellular levels (Figure 1B-C). To understand its relevance in AIDS-related lymphoma, we also tested the cell-surface expression of $\mathrm{xCT}$ on different lymphoma cell-lines. We found that among 4 Burkitt's lymphoma cell lines, BL-41 and BJAB (both are $\mathrm{KSHV}^{\text {neg }} / \mathrm{EBV}^{\text {neg }}$ ) highly expressed $\mathrm{xCT}$, AKATA $\left(\mathrm{KSHV}^{\text {neg }} / \mathrm{EBV}^{+}\right)$intermediately expressed $\mathrm{xCT}$ while RAMOS $\left(\mathrm{KSHV}^{\text {neg }} /\right.$ $\mathrm{EBV}^{\text {neg }}$ ) was lack of $\mathrm{xCT}$ expression (Additional file 1: Figure S1). In addition, one diffuse large cell lymphoma (DLCL) cell line CRL2631 (KSHV ${ }^{\text {neg }} / \mathrm{EBV}^{\text {neg }}$ ) also intermediately expressed $\mathrm{xCT}$ on cell-surface (Additional file 1: Figure S1).

\section{Targeting $\mathrm{xCT}$ induces KSHV-infected PEL cell death/ apoptosis in vitro}

To investigate the role of $x C T$ in PEL cell growth/survival, we treated them with two well-known $\mathrm{xCT}$ specific inhibitors [13], Monosodium glutamate (MSG) and Sulfasalazine (SASP). After 48-h treatment, both MSG and SASP significantly reduced cell viability for $\mathrm{BC}-1, \mathrm{BCP}-$ 1 and BCBL-1 in a dose-dependent manner by using MTT assays (Figure 2A-B). Further experiments demonstrated that MSG or SASP treatment increased proapoptotic cleaved-caspase 3 and 9 expression, while not changing $\mathrm{xCT}$ itself expression within $\mathrm{BCP}-1$ and BCBL-1 (Figure 2C). Flow cytometry analysis also indicated that MSG or SASP treatment only slightly reduced $\mathrm{xCT}$ expression on the surface of these cells (Additional file 1: Figure S2), implying that both drugs mainly block the functions of $\mathrm{xCT}$ but not affecting its expression or cellular location. By using Annexin-PI staining, we confirmed that both MSG and SASP treatment induced BCP-1and BCBL-1 cells undergoing apoptosis in a dose- and time-dependent manner (Figure 2D, Additional file 1: Figure S3). To exclude MSG- or SASPinduced cell apoptosis is due to non-specific "off-target", we used RNAi assays to directly silence $\mathrm{xCT}$ in PEL cells. As shown in Figure 2E, "knock-down" $\mathrm{xCT}$ significantly induced cell apoptosis for BCP-1 and BCBL-1, confirming the role of $\mathrm{xCT}$ in PEL cell growth/survival. Additional data indicated that inhibition of $\mathrm{xCT}$ by SASP also induced significant apoptosis for BL-41 lymphoma cells with highly expressed $\mathrm{xCT}$, while had very slight effects on RAMOS lymphoma cells with deficient $\mathrm{xCT}$ expression (Additional file 1: Figure S1 and S4).

Inhibition of $x C T$ reduces intracellular glutathione (GSH) but increasing reactive oxygen species (ROS) from KSHV-infected PEL cells

As mentioned above, expression of $\mathrm{xCT}$ on the cell membrane is essential for the uptake of cystine required for intracellular GSH synthesis, which plays an important role 


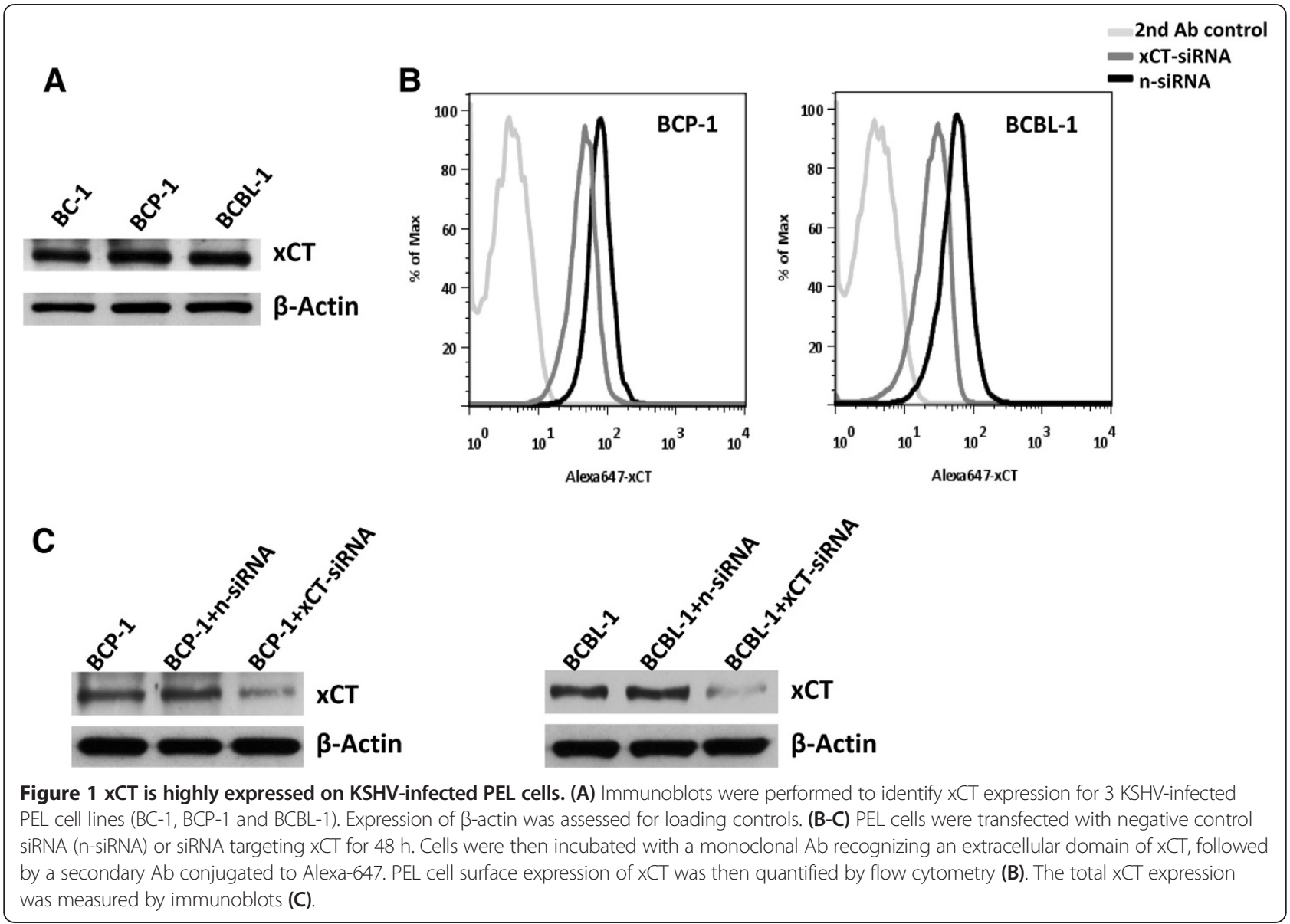

in maintaining the intracellular redox balance $[11,12]$. Therefore, we sought to determine whether MSG or SASP treatment affected intracellular GSH and ROS levels for KSHV-infected PEL cells. By using a commercial GSHassay kit, we found that both drugs apparently reduced intracellular GSH from BCP-1 and BCBL-1 cells, especially SASP (Figure 3). In contrast, impaired GSH synthesis by these $\mathrm{xCT}$ inhibitors increased intracellular ROS production within PEL cells (Figure 4A), shown by using a ROS-specific dye, 5-(and-6)-chloromethyl-2',7'-dichlorodihydrofluorescein diacetate, acetyl ester (CM-H2DCFDA) [23]. Here we used one of NF-кB inhibitors, Bay11-7082 as a positive control, because published data have shown blocking NF- $\mathrm{kB}$ pathway increasing ROS production and inducing cell apoptosis from KSHV-infected PEL [23]. As we know, ROS production requires the NADPH oxidase complex, which contains various NADPH oxidases and cytosolic components depending on the stimulus signals and cell types [24,25]. Our further data demonstrated that inhibition of $\mathrm{xCT}$ mainly upregulated the expression of Rac1/p22 $2^{\text {phox }} /$ Nox1/Nox 2 axis for ROS production, although the elevated levels are subtle different between BCP-1 and BCBL-1 cells, while very little impacts on $\mathrm{p} 47^{\text {phox }}$ and Nox4 proteins (Figure $4 \mathrm{~B}$ ). In functional validation, we confirmed that MSG and SASP treatment significantly elevated the activities of NADPH oxidases within BCP-1 and BCBL-1 (Figure 4C), using a luminescencebased biochemical assay as described previously [26]. In parallel, we found that RNAi directly silencing $\mathrm{xCT}$ also increased intracellular ROS production from BCBL-1 cells potentially through activating the Rac1/ p22 $2^{\text {phox }} /$ Nox1/Nox2 axis (Additional file 1: Figure S5). To block ROS production, we next employed one of $\mathrm{H}_{2} \mathrm{O}_{2}$ scavengers, the antioxidant $N$-acetylcysteine (NAC). We found that NAC treatment significantly reduced BCBL-1 cell apoptosis induced by $\mathrm{xCT}$ inhibitors MSG and SASP (Figure 4D), although which cannot completely prevent the induced cell apoptosis implying that other ROSindependent mechanisms are potentially involved.

\section{Akt complex activities are reduced by $\mathrm{xCT}$ inihibitors}

The Akt pathway and related molecules have been found essential for maintaining growth/survival of KSHVinfected PEL cells [7,27]. Blocking Akt complex activities by a variety of compounds induced PEL cell apoptosis and tumor progression in vitro and in vivo $[9,28,29]$. Here we found that both MSG and SASP treatment reduced the phosphorylation of Akt and downstream 

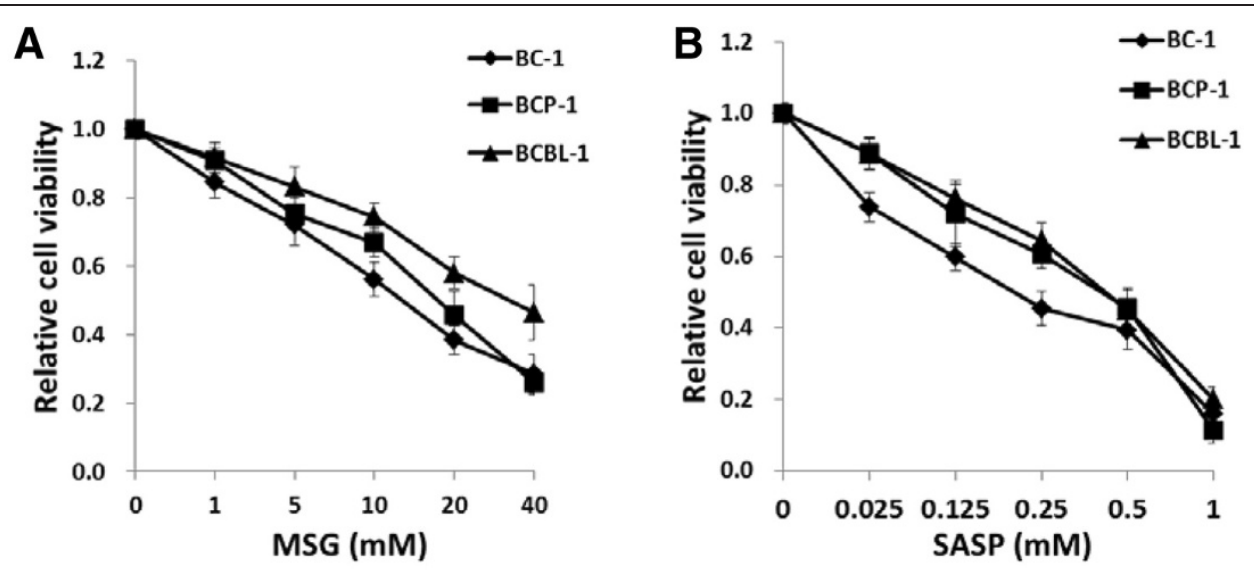

C

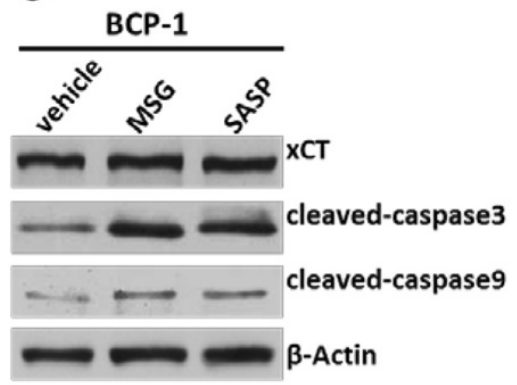

BCBL-1

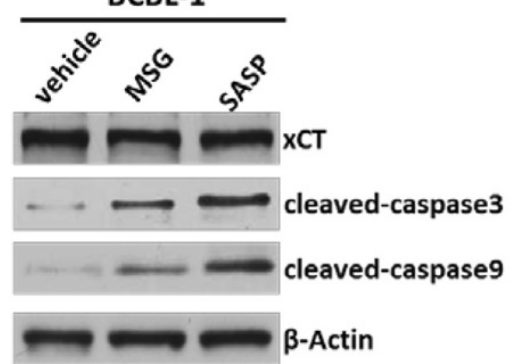

D
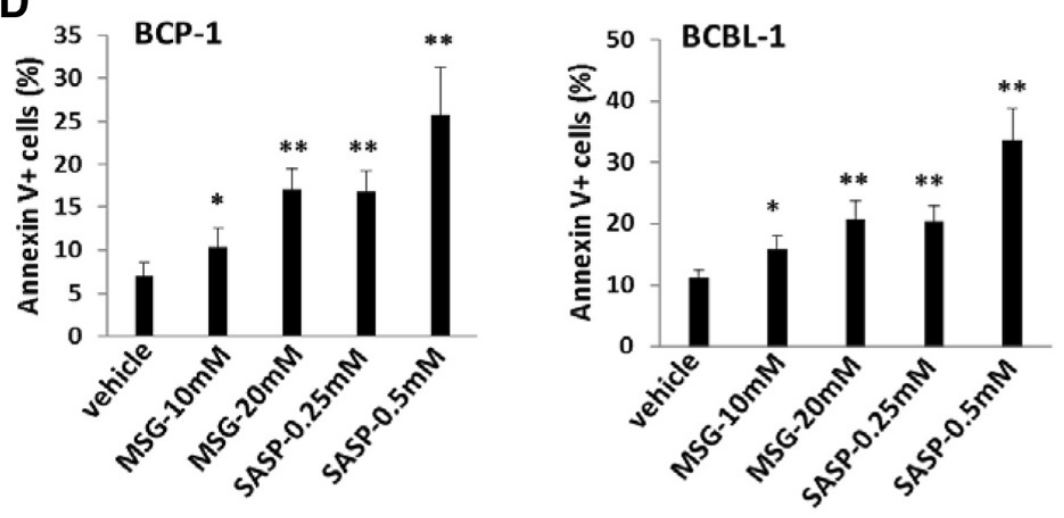

E
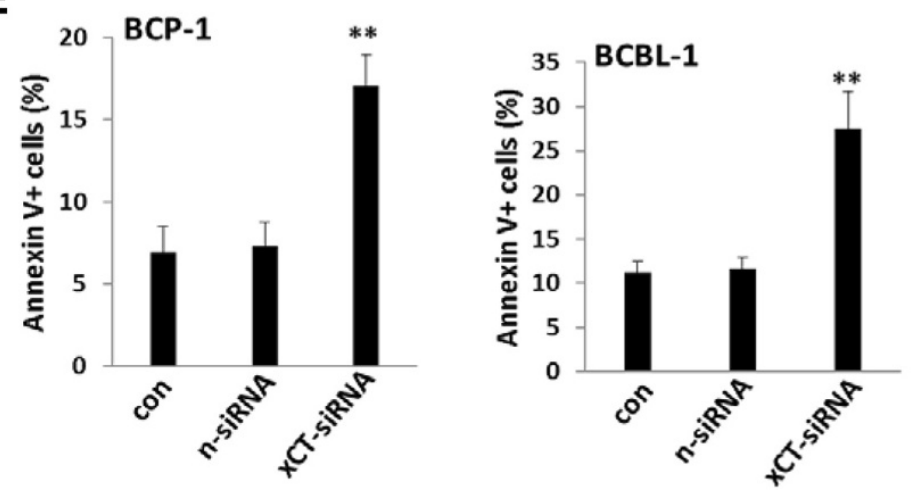

Figure $\mathbf{2}$ (See legend on next page.) 
(See figure on previous page.)

Figure 2 Targeting $x C T$ induces apoptosis and death for KSHV-infected PEL cells. (A-B) KSHV-infected BC-1, BCP-1 and BCBL-1 cells were incubated with $\times C$ T inhibitor either Monosodium glutamate (MSG), or Sulfasalazine (SASP) at the indicated concentrations for $48 \mathrm{~h}$, then cell viability was assessed by standard MTT assays. (C) BCP-1 or BCBL-1 were treated with MSG (20 mM), SASP $(0.5 \mathrm{mM})$ or vehicle for $24 \mathrm{~h}$, then proteins expression were measured by immuoblots. (D-E) BCP-1 or BCBL-1 were incubated with MSG or SASP at the indicated concentrations for $24 \mathrm{~h}$ (D), or transfected with negative control or XCT-siRNA for $48 \mathrm{~h}$ (E). Cell apoptosis was assessed using Annexin V-PI staining and flow cytometry analysis. Error bars represent the S.E.M. for 3 independent experiments. ${ }^{*}=p<0.05$; ${ }^{* *}=p<0.01$.

GSK $\alpha$ from BCP-1 and BCBL-1 (Figure 5). Moreover, SASP also effectively repressed the phosphorylation of P70S6 and S6, the two important downstream intermediates of Akt pathway [7]. We also looked at another protein, X-linked inhibitor of apoptosis protein (XIAP), a physiologic substrate of AKT that is stabilized to inhibit programmed cell death and has a direct effect on caspase- 3 and 9 [30]. Our data indicated that XIAP expression was greatly reduced in MSG- and SASPtreated PEL cells when compared with vehicle-treated cells (Figure 5). In parallel, RNAi directly silencing $\mathrm{xCT}$ also effectively reduced the phosphorylation of Akt from BCBL-1 cells (Additional file 1: Figure S5B). Taken together, these data demonstrate that the Akt pathway is indeed involved in the regulation of PEL growth/survival by $\mathrm{xCT}$.

\section{Inhibition of XCT induces viral lytic gene expression from} KSHV-infected PEL cells

PEL tumor cells are usually latently infected by KSHV with consistent expression of several viral latent proteins and microRNAs [31]. Therefore, it is interested to know whether inhibition of $\mathrm{xCT}$ has impacts on viral gene profile within these cells. Notably, we found that both MSG and SASP treatment dramatically induces viral lytic gene expression, including lytic 'switch" gene Rta and $v G p c r, v I L-6, K 8.1$, Orf57, while slightly increased latent gene Lana expression within BCP-1 and BCBL-1
(Figure 6A-B). To confirm qRT-PCR results, we detected one of viral lytic ptroteins, K8.1 expression using IFA and immunoblots. As shown in Figure 6C-D, K8.1 expression was significantly increased in the cytoplasma of MSG- or SASP-treated BCBL-1 cells, while only lowlevel of basal expression was observed in vehicle-treated cells. In parallel, RNAi directly silencing $\mathrm{xCT}$ also significantly induced viral lytic gene expression such as Rta, $v$ Gpcr and K8.1 from BCBL-1 cells (Additional file 1: Figure S6). In addition, we found that inhibition of $\mathrm{xCT}$ by MSG and SASP caused virion production from partial BCBL-1 cells (especially MSG) when compared with valproic acid, a well-known KSHV lytic chemical inducer (Figure 6E).

\section{$\mathrm{xCT}$ inhibitor suppresses PEL tumor progression in vivo}

As noted above, the $\mathrm{xCT}$ inhibitors MSG and SASP induced significant cell-apoptosis for KSHV-infected PEL in vitro. Unfortunately, MSG is a neurotoxin that precludes its use as a therapeutic agent [32]. In contrast, SASP has been routinely used in the clinic to treat inflammatory bowel disease and rheumatoid arthritis [13], induces cystine starvation and growth arrest in a variety of cancer cells in vitro and in vivo [13,15,16,33,34]. However, to our knowledge its activity against virus-associated tumors including PEL has not been explored. Therefore, we sought to determine the activity of SASP against PEL tumors in vivo utilizing an established xenograft model
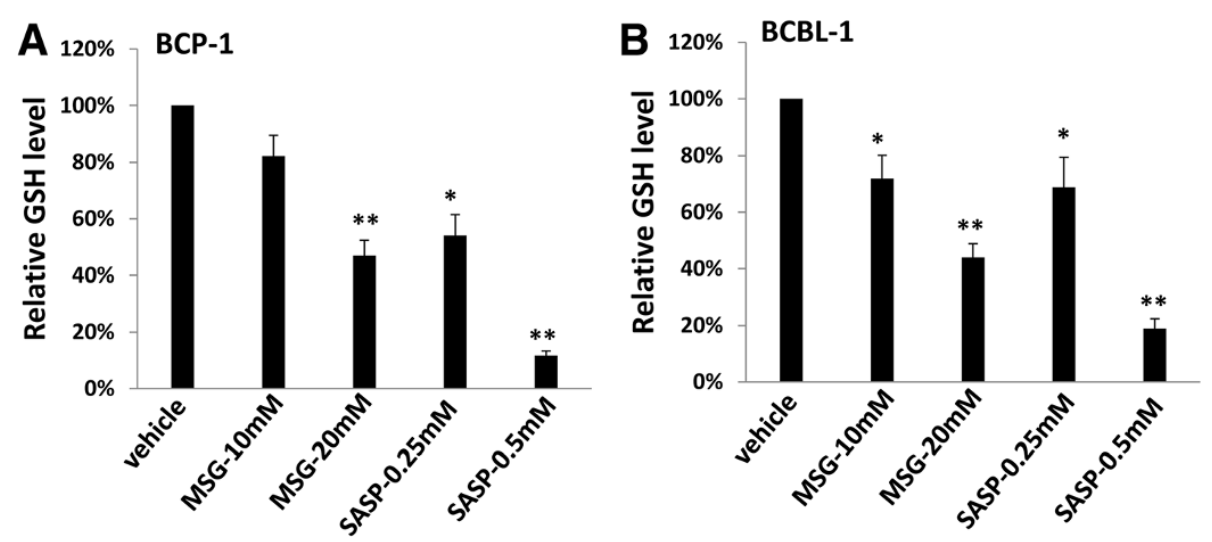

Figure 3 xCT inhibition reduces intracellular GSH levels from KSHV-infected PEL cells. (A-B) BCP-1 (A) and BCBL-1 (B) cells were incubated with either MSG or SASP at the indicated concentrations for $24 \mathrm{~h}$, then intracellular glutathione (GSH) was quantified using a commercial kit as described in Methods, and normalized to GSH levels for the vehicle-incubated cells. Error bars represent the S.E.M. for 3 independent experiments. ${ }^{*}=p<0.05 ;{ }^{* *}=p<0.01$. 


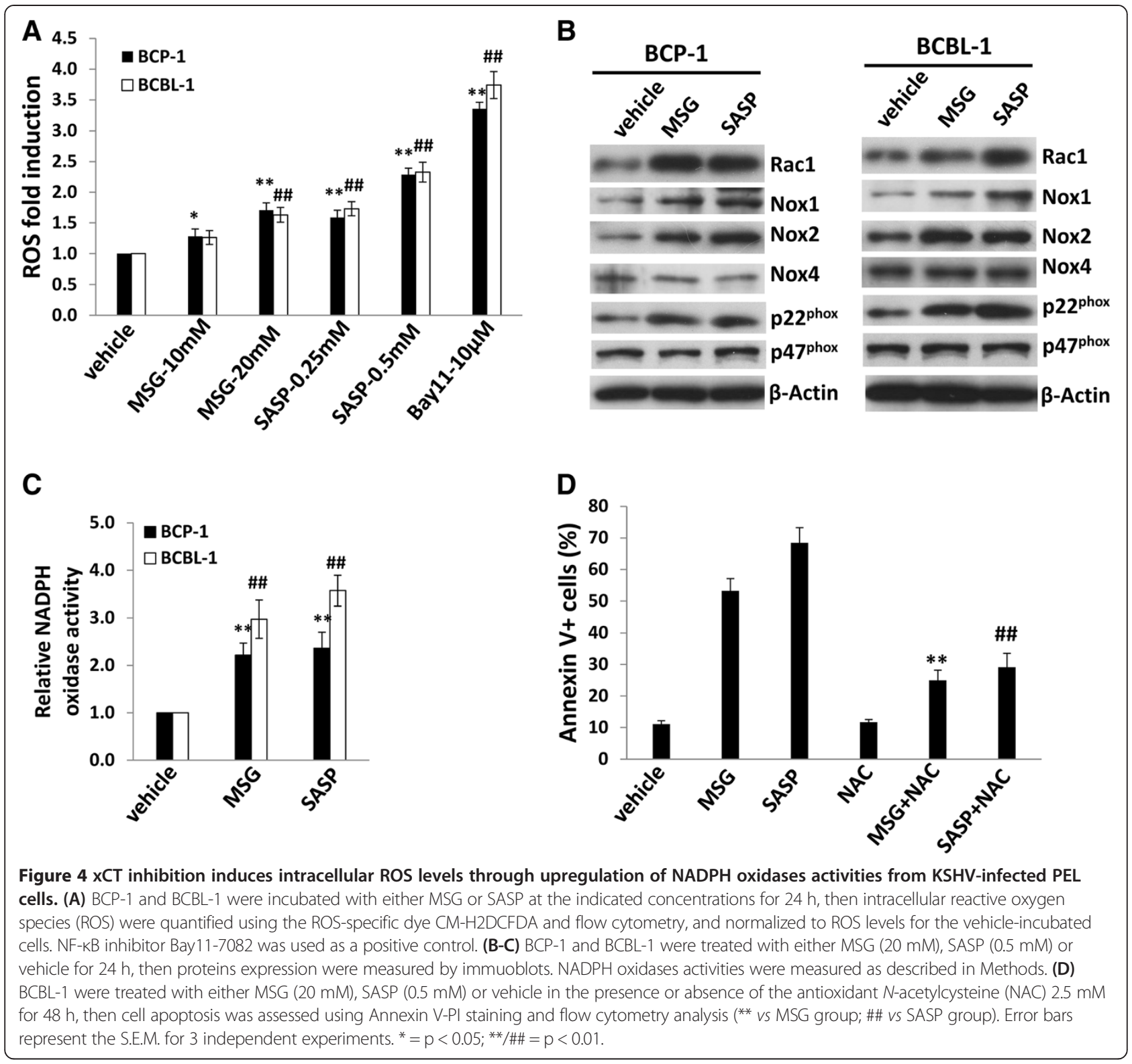

wherein PEL cells are introduced into the peritoneal cavity of immune compromised mice [9]. In this model, we injected BCBL-1 cells into NOD/SCID mice and observed clear PEL expansion within 3-4 weeks post-injection, including time-dependent weight gain and increased abdominal girth, as well as ascites accumulation and splenic enlargement due to tumor infiltration at the time of necropsy [9]. In the current study, we administered SASP $(150 \mathrm{mg} / \mathrm{kg})$ or vehicle i.p. within 24 hours of PEL cell injection. SASP treatment dramatically suppressed PEL tumor progression in vivo, including reduced weight/ tumor gain, ascites formation and splenic enlargement when compared with the vehicle-treated mice (Figure 7A-C). Using the ascites tumor cells collected and purified from vehicle- or SASP-treated mice, we found that there were much higher apoptotic cell subpopulation in ascites from SASP-treated mice than those from the vehiceltreated group (Figure 7D). We also quantified viral gene profile of ascites-derived PEL cell lysates from each group. We found that PEL cells from SASP-treated mice exhibited significantly increased expression of viral lytic genes profiled (Rta, vGpcr, K8.1), while slightly increasing the latent Lana transcripts (Figure 7E).

\section{Discussion}

As mentioned above, our published data demonstrated that $\mathrm{xCT}$ is highly expressed in advanced $\mathrm{KS}$ tumor tissues from patients and important for KSHV pathogenesis [21,22]. However, in another major KSHV-related malignancy, PEL, it is unclear whether $\mathrm{xCT}$ is expressed 

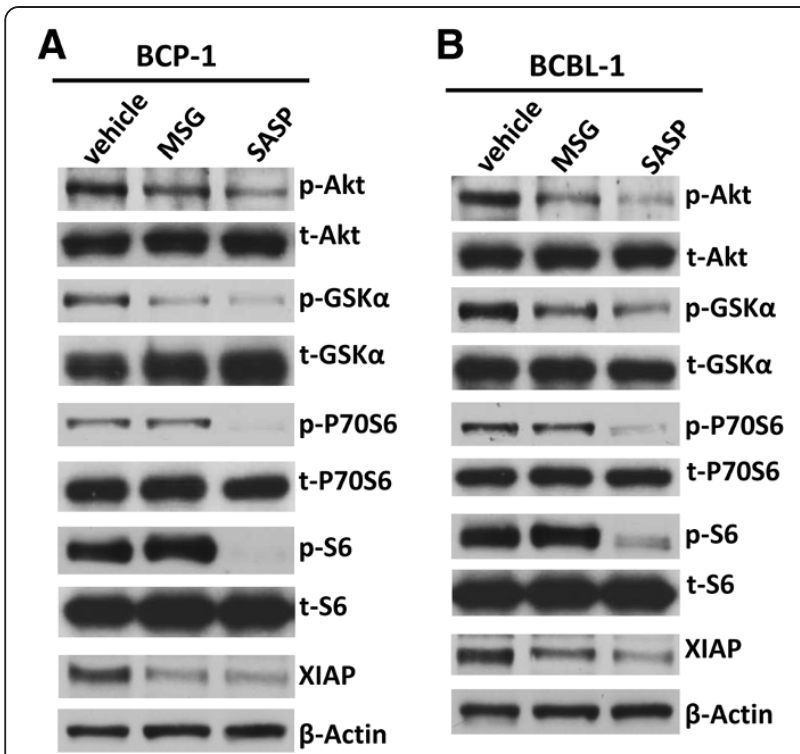

Figure 5 Targeting $\mathrm{xCT}$ blocks the Akt pathway and related protein expression. (A-B) BCP-1 (A) and BCBL-1 (B) cells were treated with either MSG $(20 \mathrm{mM})$ or SASP $(0.5 \mathrm{mM})$ for $24 \mathrm{~h}$, then protein expression were measured by immuoblots.

and functional for tumor progression. In the current study, we provide experimental evidence that $\mathrm{xCT}$ is crucial for PEL cell growth/survival and tumor expansion in vivo through the complex mechanisms involving both host and viral factors (Figure 8). Our data also indicate that targeting $\mathrm{xCT}$ alone or combination of chemotherapy may represent a promising strategy against PEL in future.

$\mathrm{xCT}$ expression is differentially regulated during oxidative stress through transcription factors binding to the cis-acting "Antioxidant Response Element" (ARE) in its promoter $[35,36]$. Transcription factors that bind to the ARE include a positive regulator known as Nuclear factor erythroid 2-related factor-2 (Nrf-2) [36] and negative regulators, including $\mathrm{BACH}-1$ and c-Maf, which competitively reduce $\mathrm{Nrf}-2$ binding to the ARE thereby repressing ARE-mediated gene expression [37,38]. We and others have confirmed that at least one KSHV-microRNA, miR-K12-11, can directly target BACH-1 to increase $\mathrm{xCT}$ expression $[21,39,40]$. In addition, c-Maf can also be directly targeted by several KSHV-microRNAs to promote endothelial cell reprogramming [41]. Therefore, it is interested to understand whether these KSHV-microRNAs expressed within PEL cells represent the major contributor to $\mathrm{xCT}$ expression and its functions in future studies.

Our data indicate that induction of PEL apoptosis by targeting $\mathrm{xCT}$ is potentially through repressing intracellular GSH, increasing ROS and viral lytic gene expression. In accordance with this, Li et al. have reported that depletion of GSH and upregulation of ROS strongly induce KSHV reactivation and final cell death for KSHV- infected PEL in vitro [23]. The authors also demonstrate that ROS is upregulated by NF- $\mathrm{kB}$ inhibition and is required for subsequent KSHV reactivation. However, we do not observe apparent NF- $\mathrm{kB}$ inhibition in MSG- or SASP-treated PEL cells when compared with vehicletreated control (data not shown), implying NF- $\mathrm{kB}$ signaling is not responsible for disruption of redox balance by targeting $\mathrm{xCT}$. On the other hand, it has been reported that ROS-induction by KSHV plays a causal role in KS oncogenesis by promoting proliferation and angiogenesis [42]. Furthermore, Rac1 is overexpressed in AIDS-KS lesions and in KSHV-infected mECK36 tumors, and the antioxidant NAC was able to completely suppress Rac1induced tumor formation in RacCA transgenic mice [43]. Interestingly, published literature indicates a close association between ROS upregulation and Akt signaling activation in a variety of cells [44-46]. In the contrary, we have found here that Akt signaling is greatly impaired while ROS production increased in MSG- or SASP-treated PEL cells. We assume the presence of other compensatory mechanisms for ROS upregulation when Akt signaling is repressed by inhibition of $\mathrm{xCT}$, although which requires further experimental validation.

In fact, $\mathrm{xCT}$ is involved in more cellular functions including multidrug resistance for cancer cells. The $\mathrm{x}_{\mathrm{c}}{ }^{-}$ transporter can mediate cellular uptake of cystine to enhance biosynthesis of glutathione, which has a major role in the protection of cells from drug-induced oxidative stress by mediating detoxification of drugs and their extrusion via multidrug resistance proteins $[17,18,47-50]$. For instance, glutathione induces a conformational change within the multidrug resistance-associated protein-1 (MRP1) and impairs its interaction with a drug and subsequent extrusion function [51]. In a pharmacogenomics approach, Huang et al. reported that linking expression of $\mathrm{xCT}$ with potency of 1,400 candidate anticancer drugs identified 39 showing positive correlations, and 296 with negative correlations [18]. Interestingly, we recently identify a membrane-protein-complex including Emmprin (CD147), LYVE-1 (a hyaluronan receptor) and BCRP (a drug-efflux pump protein), responsible for multidrug resistance of KSHV-infected PEL cells [52,53]. Therefore, future work will focus on determining whether $\mathrm{xCT}$ is also involved in this protein-complex to mediate multidrug resistance for PEL. Finally, it is interested to identify more cellular genes within PEL cells potentially regulated by $\mathrm{xCT}$, through analysis of the global gene profile changed due to inhibition of xCT using "-omics" technologies.

\section{Materials and methods}

Cell culture and reagents

Body cavity-based lymphoma cells (BCBL-1, $\mathrm{KSHV}^{+} / \mathrm{EBV}^{\text {neg }}$ ) and a Burkitt's lymphoma cell line BL-41 (KSHV ${ }^{\text {neg }}$ / $E V^{\text {neg }}$ ) were kindly provided by Dr. Dean Kedes 


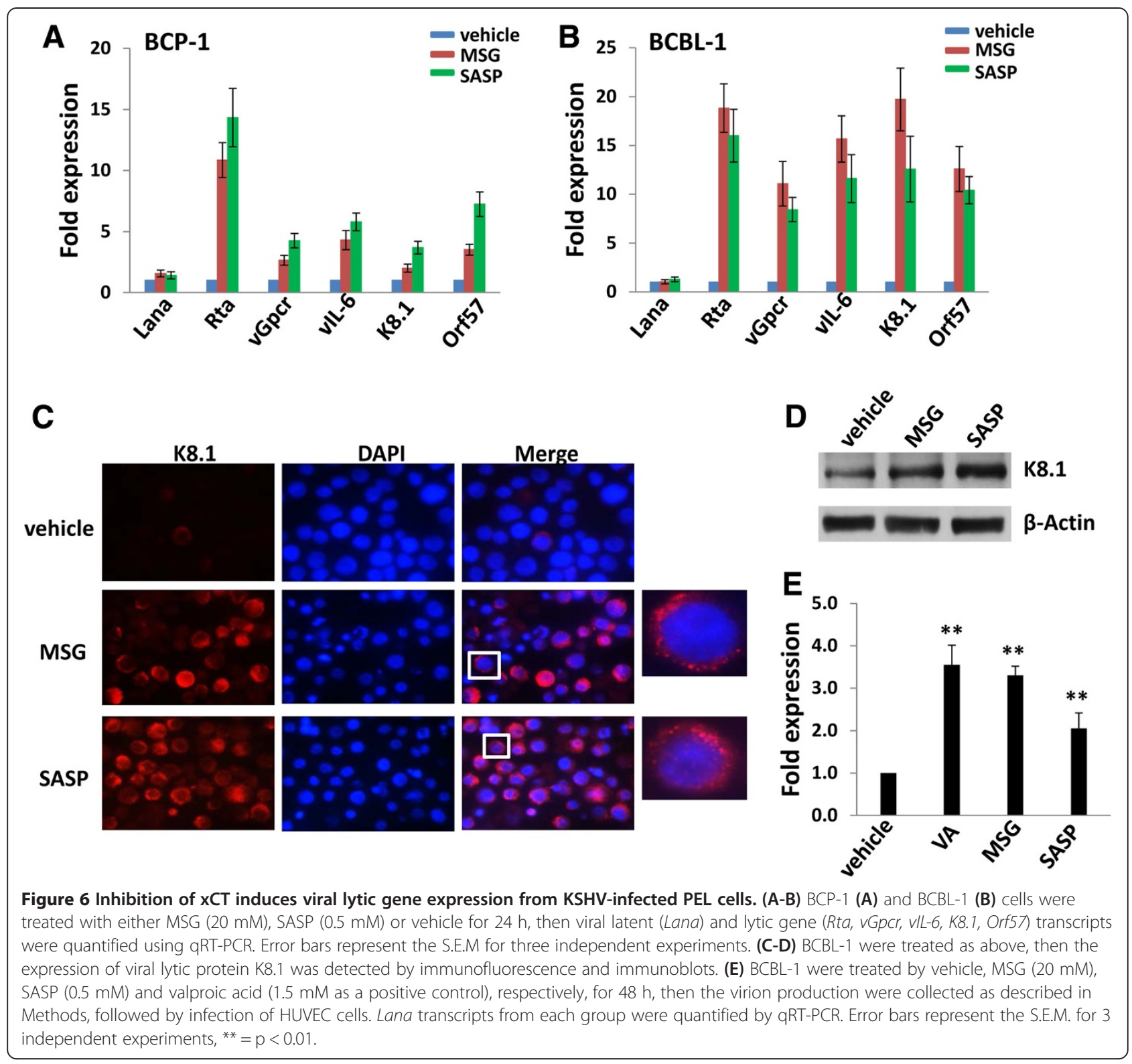

(University of Virginia) and maintained in RPMI 1640 medium (Gibco) with supplements as described previously [9]. The Burkitt's lymphoma cell line BJAB (KSHV ${ }^{\text {neg/ }}$ $\left.\mathrm{EBV}^{\text {neg }}\right)$, RAMOS (KSHV $\left.{ }^{\text {neg }} / \mathrm{EBV}^{\text {neg }}\right)$, AKATA $\left(\mathrm{KSHV}^{\text {neg }} /\right.$ $\mathrm{EBV}^{+}$) were kindly provided by Dr. Erik Flemington (Tulane University) and cultured as described elsewhere [54]. PEL cell line $\mathrm{BC}-1\left(\mathrm{KSHV}^{+} / \mathrm{EBV}^{+}\right), \mathrm{BC}-3\left(\mathrm{KSHV}^{+} / \mathrm{EBV}^{\text {neg }}\right)$, and BCP-1 (KSHV $\left.{ }^{+} / \mathrm{EBV}^{\text {neg }}\right)$ cells were purchased from American Type Culture Collection (ATCC) and maintained in complete RPMI 1640 medium (ATCC) supplemented with 20\% FBS. A diffuse large cell lymphoma (DLCL) cell line CRL2631 (KSHV $\left.{ }^{\text {neg }} / \mathrm{EBV}^{\text {neg }}\right)$ was purchased from ATCC and maintained in complete RPMI 1640 medium (ATCC) supplemented with 10\% FBS. Primary human umbilical vein endothelial cells (HUVEC) were cultured as described previously [21]. KSHV infection was verified for all cell lines using immunofluorescence assays for detection of the KSHV latency-associated nuclear antigen (LANA) [9]. All cells were cultured at $37^{\circ} \mathrm{C}$ in $5 \% \mathrm{CO}_{2}$. All experiments were carried out using cells harvested at low $(<20)$ passages. Monosodium glutamate (MSG), Sulfasalazine (SASP) and Bay11-7082 were purchased from Sigma.

Cell viability assays

Cell viability was assessed using MTT assays for assessment of proliferative capacity, and flow cytometry for quantitative assessment of apoptosis. The standard MTT assays were performed as described previously [9]. For flow cytometry, the FITC-Annexin V/propidium iodide 


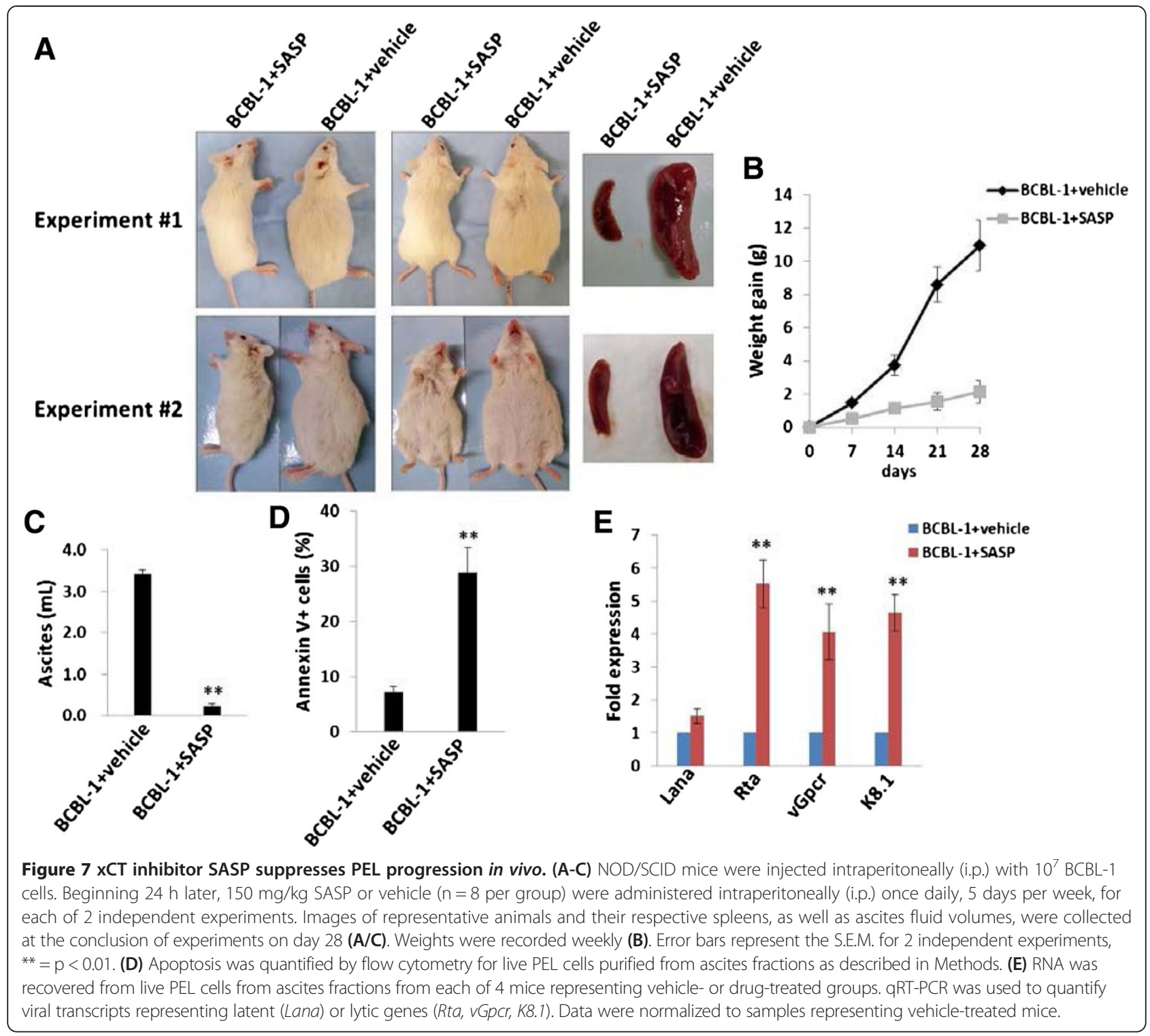

(PI) Apoptosis Detection Kit I (BD Pharmingen) were used according to the manufacturer's instructions.

\section{Immunoblotting}

Cells were lysed in buffer containing $20 \mathrm{mM}$ Tris (pH 7.5), $150 \mathrm{mM} \mathrm{NaCl}, 1 \%$ NP40, 1 mM EDTA, 5 mM $\mathrm{NaF}$ and $5 \mathrm{mM} \mathrm{Na}_{3} \mathrm{VO}_{4}$. Total cell lysates $(30 \mu \mathrm{g})$ were resolved by $10 \%$ SDS-PAGE, transferred to nitrocellulose membranes, and immunoblotted using 100-200 $\mu \mathrm{g} / \mathrm{mL}$ antibodies, including cleaved-caspase 3/9, p-Akt/t-Akt, p-GSK $\alpha / t-G S K \alpha, p-P 70 S 6 / t-P 70 S 6, p-S 6 / t-S 6, X I A P, R a c 1$ (cell signaling), Nox1 (Abcam), xCT, p22 ${ }^{\text {phox }}, \mathrm{p} 47^{\text {phox }}$, Nox2, Nox4 (Santa Cruz), KSHV-K8.1 (ABI). For loading controls, blots were reacted with antibodies detecting $\beta$ Actin (Sigma). Immunoreactive bands were developed using an enhanced chemiluminescence reaction (PerkinElmer) and visualized by autoradiography.

\section{Immunofluorescence Assays (IFA)}

Cells were incubated in 1:1 methanol-acetone at $-20^{\circ} \mathrm{C}$ for fixation and permeabilization, then with a blocking reagent ( $10 \%$ normal goat serum, $3 \%$ bovine serum albumin, and $1 \%$ glycine) for an additional 30 minutes. Cells were then incubated for $1 \mathrm{~h}$ at $25^{\circ} \mathrm{C}$ with $1: 2000$ dilution of a mouse anti-K8.1 monoclonal antibody (ABI) followed by 1:200 dilution of a goat anti-mouse secondary antibody conjugated to Texas Red (Invitrogen). For identification of nuclei, cells were subsequently counterstained with $0.5 \mu \mathrm{g} / \mathrm{mL}$ 4',6-diamidino-2-phenylindole (DAPI; Sigma) in $180 \mathrm{mM}$ Tris-HCl (pH 7.5). Cells were washed once in $180 \mathrm{mM}$ Tris- $\mathrm{HCl}$ for 15 minutes and 


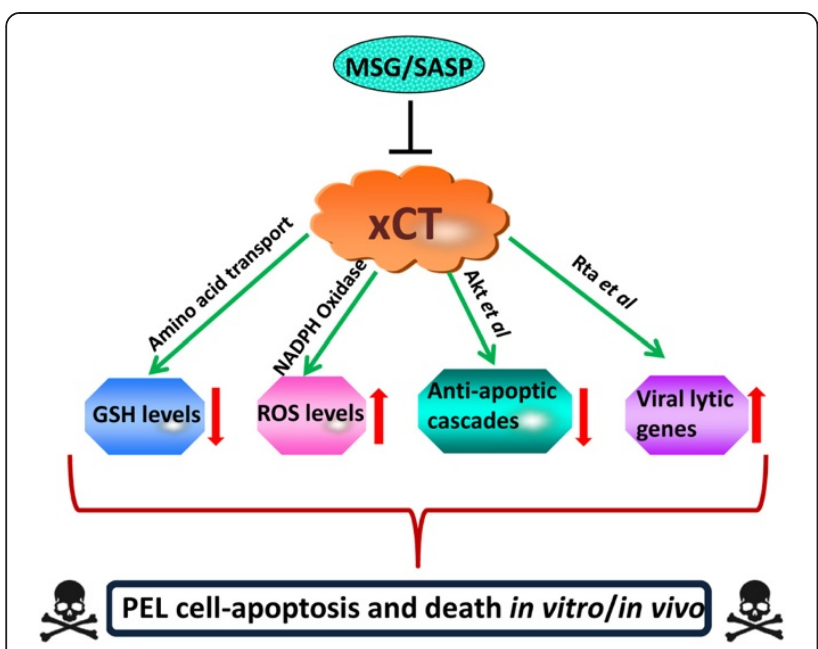

Figure 8 The model of mechanisms for inducing KSHV-infected PEL cell apoptosis and death by targeting $\mathrm{xCT}$.

prepared for visualization using a Leica TCPS SP5 AOBS confocal microscope.

\section{RNA interference}

For RNA interference assays, $\mathrm{xCT}$ ON-TARGET plus SMART pool siRNA (Dharmacon), or negative control siRNA, were delivered using the DharmaFECT transfection reagent according to the manufacturer's instructions. To confirm initial transfection efficiency for siRNA experiments, PEL cells were transfected with green fluorescent protein (GFP)-tagged siRNA, and GFP expression determined by flow cytometry $24 \mathrm{~h}$ later as described previously [9]. Three independent transfections were performed for each experiment, and all samples were analyzed in triplicate for each transfection.

\section{qRT-PCR}

Total RNA was isolated using the RNeasy Mini kit according to the manufacturer's instructions (QIAGEN). cDNA was synthesized from equivalent total RNA using SuperScript III First-Strand Synthesis SuperMix Kit (Invitrogen) according to the manufacturer's procedures. Primers used for amplification of target genes are displayed in Additional file 2: Table S1. Amplification was carried out using an iCycler IQ Real-Time PCR Detection System, and cycle threshold $(\mathrm{Ct})$ values were tabulated in duplicate for each gene of interest in each experiment. "No template" (water) controls were used to ensure minimal background contamination. Using mean $\mathrm{Ct}$ values tabulated for each gene, and paired $\mathrm{Ct}$ values for $\beta$-actin as an internal control, fold changes for experimental groups relative to assigned controls were calculated using automated iQ5 2.0 software (Bio-rad).

\section{Measurement of virion production}

BCBL-1 cells $(10 \mathrm{~mL})$ were treated by vehicle, MSG $(20 \mathrm{mM})$, SASP $(0.5 \mathrm{mM})$ and valproic acid $(1.5 \mathrm{mM}$ as a positive control), respectively, for $48 \mathrm{~h}$, then followed by centrifugation at $1200 \mathrm{rpm}$ for $5 \mathrm{~min}$ and $3000 \mathrm{rpm}$ for $20 \mathrm{~min}$. The clear supernatants were collected followed by ultracentrifugation at $30000 \mathrm{~g}$ for $2 \mathrm{~h}$, and virion pellet were resuspended at $100 \mu \mathrm{L}$ of fresh medium. The HUVEC cells were infected with these virion suspensions as described previously [22] and followed by qRT-PCR measurement of Lana transcripts mentioned above.

\section{ROS measurement}

Vehicle-, MSG- and SASP-treated PEL cells were loaded with $10 \mu \mathrm{M}$ of the ROS dye c-H2DCFDA (Invitrogen) for $30 \mathrm{~min}$ at $37^{\circ} \mathrm{C}$ in Hanks' Balanced Salt Solution (HBSS) containing calcium and magnesium (HBSS/Ca/ $\mathrm{Mg})$. Cells will be washed once with $\mathrm{HBSS} / \mathrm{Ca} / \mathrm{Mg}$ to remove dye, resuspended in $\mathrm{HBSS} / \mathrm{Ca} / \mathrm{Mg}$ and subjected to flow cytometry analyses as described elsewhere [23]. To block ROS production, PEL cells were treated with MSG, SASP or vehicle in the presence or absence of the antioxidant $N$-acetylcysteine (NAC) $2.5 \mathrm{mM}$ for $48 \mathrm{~h}$, then cell apoptosis was assessed as described above.

\section{Flow cytometry}

Cells were resuspended in staining buffer ( 3 BSA in $1 \times$ PBS) for 20 minutes, then incubated on ice for $30 \mathrm{~min}$ with 1:20 dilution of primary antibody $\mathrm{xCT}$ (Santa Cruz). Following two subsequent wash steps, cells were incubated for an additional 30 min with 1:200 dilution of secondary antibodies (Invitrogen) including Donkey anti-goat IgG Alexa Fluor 647. Controls included cells incubated with the secondary antibody only. Cells were resuspended in $1 \times$ PBS and analyzed using a FACS Calibur 4-color flow cytometer (BD) and FlowJo software (TreeStar) to quantify cell surface localization of target proteins.

\section{NADPH oxidase activities assays}

The chemiluminescence-based NADPH oxidase activities assays were performed as described previously with modifications [26]. After drug-treatment, cells were centrifuged at $500 \mathrm{~g}$ for $10 \mathrm{~min}$ at $4^{\circ} \mathrm{C}$. The cell pellet was resuspended with $35 \mu \mathrm{L}$ ice-cold lysis buffer and kept on ice for $20 \mathrm{~min}$. To a final $200 \mu \mathrm{l}$ of HBSS/Ca/Mg buffer containing NADPH ( $1 \mu \mathrm{M}$, Sigma) and lucigenin $(20 \mu \mathrm{M}$, Sigma), $5 \mu \mathrm{l}$ of cell lysates was added to initiate the reaction for $5 \mathrm{~min}$ at $37^{\circ} \mathrm{C}$. Chemiluminescence was measured immediately using a Synergy HT microplate reader (BioTek Instruments).

\section{Intracellular GSH measurement}

The intracellular GSH levels in vehicle-, MSG- and SASP-treated PEL cells were quantified using the GSH- 
Glo $^{\text {tw }}$ Glutathione Assay Kit (Promega), according to the manufacturer's instructions.

\section{PEL xenograft model}

BCBL-1 cells maintained at early passage number in cell culture were washed twice in sterile-filtered PBS prior to performance of trypan blue and flow cytometry assays for verification of their viability. Aliquots of $10^{7}$ viable cells were diluted in $200 \mu \mathrm{L}$ sterile PBS, and 6-8 weekold male non-obese diabetic/severe-combined immunodeficient (NOD/SCID) mice (Jackson Laboratory, Taconic Inc.) received intraperitoneal (i.p.) injections with a single cell aliquot. SASP solutions were prepared at $20 \mathrm{mg} / \mathrm{mL}$, dissolved in $0.1 \mathrm{~N} \mathrm{NaOH}$ in PBS at $\mathrm{pH} 7.2$, and sterilefiltered prior to in vivo administration. The SASP (150 mg/kg body weight), or vehicle alone, was administered using an insulin syringe for i.p. injection. Drug was administered 24 h after BCBL-1 injection, once daily for 5 days/week. Two experiments, with 8 mice per group for each experiment, were performed. The PEL expansion in vivo was confirmed by testing the expression of cellsurface markers including CD45, CD138, EMA and viral protein LANA in nuclear within ascites tumor cells, using IFA and flow cytometry as described in our previous publications [9]. Weights were recorded weekly as a surrogate measure of tumor progression, and ascites fluid volumes were tabulated for individual mice at the completion of each experiment. All protocols were approved by the Louisiana State University Health Science Center Animal Care and Use Committee in accordance with national guidelines.

\section{Statistical analyses}

Significance for differences between experimental and control groups was determined using the two-tailed Student's t-test (Excel 8.0).

\section{Additional files}

Additional file 1: Figure S1. xCT expression on cell-surface of AIDS-related lymphoma. Figure S2. xCT expression on the surface of vehicle-, MSG- or SASP-treated PEL cells. Figure S3. Targeting xCT induces apoptosis for KSHV-infected PEL cells. Figure S4. Targeting xCT induces apoptosis for AIDS-related lymphoma. Figure S5. Targeting XCT by RNAi induces intracellular ROS levels through upregulation of NADPH oxidases from KSHV-infected PEL cells. Figure S6. Targeting $x C T$ by RNAi induces viral lytic gene expression from KSHV-infected PEL cells.

Additional file 2: Table S1. Primer sequences for qRT-PCR in this study.

\section{Competing interests}

The authors declare that they have no competing interests.

\section{Authors' contributions}

Participated in research design: LD, ZQ. Conducted experiments: LD, YC, ZQ. Performed data analysis: LD, YC, ZQ. Wrote or contributed to the writing of the manuscript: $L D, Y C, C P, Z Q$. All authors read and approved the final manuscript.

\section{Acknowledgement}

This work was supported by grants from the National Institutes of Health (R01-CA142362), a Center for Biomedical Research Excellence Award (P20-RR021970), the SOM Research Enhancement Funding (5497400038), the Ladies Leukemia League Grant (2014-2015), the National Natural Science Foundation (81272191), the NNSF for Young Scientists of China (81101791) and the Foundation for Innovative Research Groups of the National Natural Science Foundation of China (81221001). The funders had no role in study design, data collection and analysis, decision to publish, or preparation of the manuscript.

\section{Author details}

${ }^{1}$ Research Center for Translational Medicine and Key Laboratory of Arrhythmias of the Ministry of Education of China, East Hospital, Tongji University School of Medicine, 150 Jimo Road, Shanghai 200120, China. ${ }^{2}$ Department of Microbiology/Immunology/Parasitology, Louisiana State University Health Sciences Center, Louisiana Cancer Research Center, 1700 Tulane Ave., New Orleans, LA 70112, USA. ${ }^{3}$ Department of Medicine, Louisiana State University Health Sciences Center, Louisiana Cancer Research Center, 1700 Tulane Ave., New Orleans, LA 70112, USA.

Received: 25 February 2014 Accepted: 30 March 2014 Published: 4 April 2014

\section{References}

1. Chang Y, Cesarman E, Pessin MS, Lee F, Culpepper J, Knowles DM, Moore PS: Identification of herpesvirus-like DNA sequences in AIDS-associated Kaposi's sarcoma. Science 1994, 266(5192):1865-1869.

2. Cesarman E, Chang Y, Moore PS, Said JW, Knowles DM: Kaposi's sarcomaassociated herpesvirus-like DNA sequences in AIDS-related body-cavitybased lymphomas. N Engl J Med 1995, 332(18):1186-1191.

3. Chen YB, Rahemtullah A, Hochberg E: Primary effusion lymphoma. Oncologist 2007, 12(5):569-576.

4. Simonelli C, Spina M, Cinelli R, Talamini R, Tedeschi R, Gloghini A, Vaccher E, Carbone A, Tirelli U: Clinical features and outcome of primary effusion lymphoma in HIV-infected patients: a single-institution study. J Clin Oncol 2003, 21(21):3948-3954.

5. Valencia ME, Martinez P, Moreno V, Laguna F, Lahoz JG: AIDS-related body cavity-based lymphomas, herpesvirus- 8 and HIV infection: a study of seven cases. AIDS 1999, 13(18):2603-2605.

6. Boulanger E, Gerard L, Gabarre J, Molina JM, Rapp C, Abino JF, Cadranel J, Chevret S, Oksenhendler E: Prognostic factors and outcome of human herpesvirus 8-associated primary effusion lymphoma in patients with AIDS. J Clin Oncol 2005, 23(19):4372-4380.

7. Sin SH, Roy D, Wang L, Staudt MR, Fakhari FD, Patel DD, Henry D, Harrington WJ Jr, Damania BA, Dittmer DP: Rapamycin is efficacious against primary effusion lymphoma (PEL) cell lines in vivo by inhibiting autocrine signaling. Blood 2007, 109(5):2165-2173.

8. Chaisuparat R, Hu J, Jham BC, Knight ZA, Shokat KM, Montaner S: Dual inhibition of PI3Kalpha and mTOR as an alternative treatment for Kaposi's sarcoma. Cancer Res 2008, 68(20):8361-8368.

9. Qin Z, Dai L, Trillo-Tinoco J, Senkal C, Wang W, Reske T, Bonstaff K, Del Valle L, Rodriguez P, Flemington E, Voelkel-Johnson C, Smith CD, Ogretmen B, Parsons C: Targeting sphingosine kinase induces apoptosis and tumor regression for KSHV-associated primary effusion lymphoma. Mol Cancer Ther 2014, 13(1):154-164.

10. Bannai S, Kitamura E: Transport interaction of L-cystine and L-glutamate in human diploid fibroblasts in culture. J Biol Chem 1980, 255(6):2372-2376.

11. Bannai $\mathrm{S}$ : Exchange of cystine and glutamate across plasma membrane of human fibroblasts. J Biol Chem 1986, 261(5):2256-2263.

12. Patel SA, Warren BA, Rhoderick JF, Bridges RJ: Differentiation of substrate and non-substrate inhibitors of transport system xc(-): an obligate exchanger of L-glutamate and L-cystine. Neuropharmacology 2004, 46(2):273-284

13. Gout PW, Buckley AR, Simms CR, Bruchovsky N: Sulfasalazine, a potent suppressor of lymphoma growth by inhibition of the $x(c)$ - cystine transporter: a new action for an old drug. Leukemia 2001, 15(10):1633-1640

14. Chung WJ, Lyons SA, Nelson GM, Hamza H, Gladson CL, Gillespie GY, Sontheimer $\mathrm{H}$ : Inhibition of cystine uptake disrupts the growth of primary brain tumors. J Neurosci 2005, 25(31):7101-7110. 
15. Narang VS, Pauletti GM, Gout PW, Buckley DJ, Buckley AR: Suppression of cystine uptake by sulfasalazine inhibits proliferation of human mammary carcinoma cells. Anticancer Res 2003, 23(6C):4571-4579.

16. Doxsee DW, Gout PW, Kurita T, Lo M, Buckley AR, Wang Y, Xue H, Karp CM, Cutz JC, Cunha GR, Wang YZ: Sulfasalazine-induced cystine starvation: potential use for prostate cancer therapy. Prostate 2007, 67(2):162-171.

17. Okuno S, Sato H, Kuriyama-Matsumura K, Tamba M, Wang H, Sohda S, Hamada H, Yoshikawa H, Kondo T, Bannai S: Role of cystine transport in intracellular glutathione level and cisplatin resistance in human ovarian cancer cell lines. Br J Cancer 2003, 88(6):951-956.

18. Huang Y, Dai Z, Barbacioru C, Sadee W: Cystine-glutamate transporter SLC7A11 in cancer chemosensitivity and chemoresistance. Cancer Res 2005, 65(16):7446-7454.

19. Kaleeba JA, Berger EA: Kaposi's sarcoma-associated herpesvirus fusion-entry receptor: cystine transporter xCT. Science 2006, 311(5769):1921-1924.

20. Veettil MV, Sadagopan S, Sharma-Walia N, Wang FZ, Raghu H, Varga L, Chandran B: Kaposi's sarcoma-associated herpesvirus forms a multimolecular complex of integrins (alphaVbeta5, alphaVbeta3, and alpha3beta1) and CD98-xCT during infection of human dermal microvascular endothelial cells, and CD98-xCT is essential for the postentry stage of infection. J Virol 2008, 82(24):12126-12144.

21. Qin Z, Freitas E, Sullivan R, Mohan S, Bacelieri R, Branch D, Romano M, Kearney P, Oates J, Plaisance K, Renne R, Kaleeba J, Parsons C: Upregulation of $\mathrm{xCT}$ by KSHV-encoded microRNAs facilitates KSHV dissemination and persistence in an environment of oxidative stress. PLOS Pathog 2010, 6(1):e1000742.

22. Qin Z, Dai L, Defee M, Findlay VJ, Watson DK, Toole BP, Cameron J, Peruzzi F, Kirkwood K, Parsons C: Kaposi's sarcoma-associated herpesvirus suppression of DUSP1 facilitates cellular pathogenesis following de novo infection. J Virol 2013, 87(1):621-635.

23. Li X, Feng J, Sun R: Oxidative stress induces reactivation of Kaposi's sarcoma-associated herpesvirus and death of primary effusion lymphoma cells. J Virol 2011, 85(2):715-724.

24. Lambeth JD: NOX enzymes and the biology of reactive oxygen. Nat Rev Immunol 2004, 4(3):181-189.

25. Bedard K, Krause KH: The NOX family of ROS-generating NADPH oxidases: physiology and pathophysiology. Physiol Rev 2007, 87(1):245-313.

26. Lee JM, Kim SS, Cho YS: The Role of PPARgamma in Helicobacter pylori Infection and Gastric Carcinogenesis. PPAR Res 2012, 2012:687570.

27. Bhatt AP, Damania B: AKTivation of PI3K/AKT/mTOR signaling pathway by KSHV. Front Immunol 2012, 3:401.

28. Uddin S, Hussain AR, Al-Hussein KA, Manogaran PS, Wickrema A, Gutierrez MI, Bhatia KG: Inhibition of phosphatidylinositol 3'-kinase/AKT signaling promotes apoptosis of primary effusion lymphoma cells. Clin Cancer Res 2005, 11(8):3102-3108.

29. Bhatt AP, Bhende PM, Sin SH, Roy D, Dittmer DP, Damania B: Dual inhibition of PI3K and mTOR inhibits autocrine and paracrine proliferative loops in PI3K/Akt/mTOR-addicted lymphomas. Blood 2010, 115(22):4455-4463.

30. Dan HC, Sun M, Kaneko S, Feldman Rl, Nicosia SV, Wang HG, Tsang BK, Cheng JQ: Akt phosphorylation and stabilization of X-linked inhibitor of apoptosis protein (XIAP). J Biol Chem 2004, 279(7):5405-5412.

31. Carbone A, Cesarman E, Gloghini A, Drexler HG: Understanding pathogenetic aspects and clinical presentation of primary effusion lymphoma through its derived cell lines. AIDS 2010, 24(4):479-490.

32. Choi DW: Ionic dependence of glutamate neurotoxicity. J Neurosci 1987, 7(2):369-379.

33. Gout PW, Simms CR, Robertson MC: In vitro studies on the lymphoma growth-inhibitory activity of sulfasalazine. Anticancer Drugs 2003, 14(1):21-29

34. Lo M, Ling V, Low C, Wang YZ, Gout PW: Potential use of the antiinflammatory drug, sulfasalazine, for targeted therapy of pancreatic cancer. Curr Oncol 2010, 17(3):9-16

35. Sasaki H, Sato H, Kuriyama-Matsumura K, Sato K, Maebara K, Wang H, Tamba M, Itoh K, Yamamoto M, Bannai S: Electrophile response elementmediated induction of the cystine/glutamate exchange transporter gene expression. J Biol Chem 2002, 277(47):44765-44771.

36. Ishii $T$, Itoh $K$, Takahashi S, Sato H, Yanagawa T, Katoh Y, Bannai S, Yamamoto M: Transcription factor Nrf2 coordinately regulates a group of oxidative stress-inducible genes in macrophages. J Biol Chem 2000, 275(21):16023-16029.
37. Dhakshinamoorthy S, Jain AK, Bloom DA, Jaiswal AK: Bach1 competes with Nrf2 leading to negative regulation of the antioxidant response element (ARE)-mediated NAD(P)H:quinone oxidoreductase 1 gene expression and induction in response to antioxidants. J Biol Chem 2005, 280(17):16891-16900.

38. Dhakshinamoorthy S, Jaiswal AK: c-Maf negatively regulates ARE-mediated detoxifying enzyme genes expression and anti-oxidant induction. Oncogene 2002, 21(34):5301-5312.

39. Skalsky RL, Samols MA, Plaisance KB, Boss IW, Riva A, Lopez MC, Baker HV, Renne R: Kaposi's sarcoma-associated herpesvirus encodes an ortholog of miR-155. J Virol 2007, 81(23):12836-12845

40. Gottwein E, Mukherjee N, Sachse C, Frenzel C, Majoros WH, Chi JT, Braich R, Manoharan M, Soutschek J, Ohler U, Cullen BR: A viral microRNA functions as an orthologue of cellular miR-155. Nature 2007, 450(7172):1096-1099.

41. Hansen A, Henderson S, Lagos D, Nikitenko L, Coulter E, Roberts S, Gratrix F, Plaisance K, Renne R, Bower M, Kellam P, Boshoff C: KSHV-encoded miRNAs target MAF to induce endothelial cell reprogramming. Genes Dev 2010, 24(2):195-205.

42. Ma Q, Cavallin LE, Leung HJ, Chiozzini C, Goldschmidt-Clermont PJ, Mesri EA: A role for virally induced reactive oxygen species in Kaposi's sarcoma herpesvirus tumorigenesis. Antioxid Redox Signal 2013, 18(1):80-90.

43. Ma Q, Cavallin LE, Yan B, Zhu S, Duran EM, Wang H, Hale LP, Dong C, Cesarman E, Mesri EA, Goldschmidt-Clermont PJ: Antitumorigenesis of antioxidants in a transgenic Rac1 model of Kaposi's sarcoma. Proc Natl Acad Sci U S A 2009, 106(21):8683-8688.

44. Li L, Dong H, Song E, Xu X, Liu L, Song Y: Nrf2/ARE pathway activation, HO-1 and NQO1 induction by polychlorinated biphenyl quinone is associated with reactive oxygen species and PI3K/AKT signaling. Chem Biol Interact 2013, 209C:56-67.

45. Kundu J, Kim DH, Kundu JK, Chun KS: Thymoquinone induces heme oxygenase-1 expression in $\mathrm{HaCaT}$ cells via Nrf2/ARE activation: Akt and AMPKalpha as upstream targets. Food Chem Toxicol 2013, 65C:18-26.

46. Chen S, Ren Q, Zhang J, Ye Y, Zhang Z, Xu Y, Guo M, Ji H, Xu C, Gu C, Gao W, Huang $S$, Chen L: N-acetyl-L-cysteine protects against cadmiuminduced neuronal apoptosis by inhibiting ROS-dependent activation of Akt/mTOR pathway in mouse brain. Neuropathol Appl Neurobiol 2013. doi:10.1111/nan.12103. [Epub ahead of print].

47. Haimeur A, Deeley RG, Cole SP: Charged amino acids in the sixth transmembrane helix of multidrug resistance protein 1 (MRP1/ABCC1) are critical determinants of transport activity. J Biol Chem 2002, 277(44):41326-41333.

48. Filipits M, Pohl G, Rudas M, Dietze O, Lax S, Grill R, Pirker R, Zielinski CC, Hausmaninger $H$, Kubista E, Samonigg $H$, Jakesz R: Clinical role of multidrug resistance protein 1 expression in chemotherapy resistance in early-stage breast cancer: the Austrian Breast and Colorectal Cancer Study Group. J Clin Oncol 2005, 23(6):1161-1168.

49. Yang P, Ebbert JO, Sun Z, Weinshilboum RM: Role of the glutathione metabolic pathway in lung cancer treatment and prognosis: a review. J Clin Oncol 2006, 24(11):1761-1769.

50. Yadav S, Zajac E, Singhal SS, Awasthi S: Linking stress-signaling, glutathione metabolism, signaling pathways and xenobiotic transporters. Cancer Metastasis Rev 2007, 26(1):59-69.

51. Uchino H, Kanai Y, Kim DK, Wempe MF, Chairoungdua A, Morimoto E, Anders MW, Endou H: Transport of amino acid-related compounds mediated by L-type amino acid transporter 1 (LAT1): insights into the mechanisms of substrate recognition. Mol Pharmacol 2002, 61(4):729-737.

52. Qin Z, Dai L, Bratoeva M, Slomiany MG, Toole BP, Parsons C: Cooperative roles for emmprin and LYVE-1 in the regulation of chemoresistance for primary effusion lymphoma. Leukemia 2011, 25(10):1598-1609.

53. Dai L, Bai L, Lu Y, Xu Z, Reiss K, Del Valle L, Kaleeba J, Toole BP, Parsons C, Qin Z: Emmprin and KSHV: new partners in viral cancer pathogenesis. Cancer Lett 2013, 337(2):161-166.

54. Lin Z, Puetter A, Coco J, Xu G, Strong MJ, Wang X, Fewell C, Baddoo M, Taylor C, Flemington EK: Detection of murine leukemia virus in the Epstein-Barr virus-positive human B-cell line JY, using a computational RNA-Seq-based exogenous agent detection pipeline, PARSES. J Virol 2012, 86(6):2970-2977.

doi:10.1186/1756-8722-7-30

Cite this article as: Dai et al:: Targeting $\mathrm{xCT}$, a cystine-glutamate transporter induces apoptosis and tumor regression for KSHV/HIV-associated lymphoma. Journal of Hematology \& Oncology 2014 7:30. 